\title{
The Relationship between English Language Learner Characteristics and Online Self-regulation: A Structural Equation Modeling Approach
}

\author{
Wei Wang ${ }^{1, *}$ and Ju Zhan ${ }^{1,2}$ \\ 1 College of Humanities, Jilin University, Changchun 130012, China \\ 2 School of Foreign Language Education, Jilin University, Changchun 130012, China \\ * Correspondence: weiw18@mails.jlu.edu.cn
}

Received: 4 March 2020; Accepted: 8 April 2020; Published: 9 April 2020

check for updates

\begin{abstract}
Learner beliefs, anxiety, and motivation are three common learner characteristics. They have consistently been found to account for language learning performance. Meanwhile, self-regulation is critical in sustaining online learners' continuous efforts and predicting their learning outcomes. Despite the massive and rapidly increasing number of online English learners, few studies have clarified the assumed relationships between learner characteristics (learner beliefs, anxiety, motivation) and self-regulation in the online English learning context. This study aims to fill the gap by conducting structural equation modeling analysis to examine their relations. To fulfill the research purpose, we adopted the previous questionnaires with sufficient reliability as instruments to evaluate students' online English learner beliefs, learning anxiety, learning motivation and online self-regulated English learning. The valid responses collected from 425 Chinese undergraduate university students enrolled in an online academic English writing course provided the data source. The results indicated that learner beliefs positively predicted, while learning anxiety negatively predicted, online self-regulated English learning. Online English learning motivation was a mediator in these associations. The findings suggested that stronger learner beliefs of self-efficacy and perceived value of English learning promoted learning motivation and self-regulation. In contrast, higher learning anxiety, such as test anxiety and fear of negative evaluation, harmed learners' motivation and their online self-regulated English learning.
\end{abstract}

Keywords: online English learner beliefs; online English learning anxiety; online English learning motivation; online self-regulated English learning; structural equation model; mediating role of learning motivation

\section{Introduction}

Recent years have witnessed a rapid growth in the number of English-as-a-foreign-language (EFL) learners at tertiary level [1,2]. Along with this phenomenon is the popularity of online English courses among Chinese university students [2]. The emerging and addition of technology-enhanced learning activities into foreign language learning courses represents a new development trend. To be specific, the technological tools designed for online learning, such as "Blackboard", screen sharing, interactive forums, videoconferencing, and learning materials sharing, etc., provide easier access for foreign language learners to expand their resources and tools [3,4]. Besides, the widespread use of the Internet and mobile technology enables students to self-direct their online language learning process [3-5]. This sets up a new learning environment compared to traditional classroom teaching. Admittedly, it is highly demanding to proficiently master a foreign language [6]. When confronted with difficulties in the course of English learning, learners normally turn to complex strategies that 
integrate cognitive, affective and behavioral factors, so as to achieve a continuous learning outcome. Among these, learner beliefs, anxiety, motivation and self-regulation are intensively studied [1-7].

Three learner characteristics are commonly and consistently found to account for foreign language learning performance, namely learner beliefs, anxiety and motivation [7-10]. To be specific, language learning beliefs are critical because they impose strong impacts on how students evaluate and utilize language learning strategies. Language learners, for instance, may hold different opinions on what accounts for a successful foreign language learning. Some think learning English grammar and vocabulary is the major task, while others contend that it is important to use and speak English in an appropriate language environment [11]. Foreign language learning anxiety includes uncomfortable feelings in using or learning a foreign language. Such anxiety is common among Chinese English-as-a-foreign language (EFL) learners with different proficiency levels. Most English learners, especially for those at beginner levels, feel more anxious when they are singled out to speak English or use English to respond to the teacher in class. English learners with a higher level of foreign language anxiety may form a mental block which greatly hinders foreign language learning efficiency [12]. It was also found that foreign language speaking and listening are more anxiety-provoking than writing and listening [13]. Motivation not only involves the reasons for language learning, but also the intensity of the language learners' feelings. For example, some Chinese university students learn English only for the purpose of meeting a minimum language requirement to obtain their academic degree, while others see English as a tool and expect to use English in their future career. In comparison, people who learn English for career purpose (process-focused motivation) may have a stronger motivation than those who only expect to pass an English test (outcome-focused motivation) [14,15].

Meanwhile, the evidence is mounting that the active control and utilization of self-regulatory strategies make it possible for foreign language learners to gradually improve their language competence and keep their intention focused on the target of foreign language learning [16,17]. As indicated by Zimmerman and Schunk and Zimmerman [18,19], the self-generated thoughts, feelings, behaviors and strategies of learners largely actually trigger and contribute to language learning, which is oriented towards a proficient use of the target foreign language. The self-regulated learning is a cyclic process in which students make plans for a specific language learning task, monitor their performance in a timely manner, and finally summarize and reflect on their outcome [20,21]. The learners' self-regulated learning does not automatically happen, but involves the sufficient social engagement of language learners, which includes interactions, communications, feedback, comments and group discussions. The procedures repeat when language learners apply the previous reflections to prepare for and guide the next task. The whole process is not universal, but should be individualized in a specific language learning task [18-21]. In this sense, the self-regulated learning model is intrinsically learners-oriented, and thus naturally correlated with learner characteristics.

Past studies have explored the separate role of learner beliefs, anxiety and motivation in improving foreign language learning outcomes $[10-12,15,18]$. However, their interactions still remain obscure in an online English-learning context. In addition, despite the close relationship between foreign language learner characteristics and self-regulated learning, few studies have systematically examined how learner beliefs, anxiety and motivation concurrently influence self-regulated English learning, especially in a web-based environment. Accordingly, we expect that learner beliefs and motivation positively predict self-regulation, while anxiety negatively predicts self-regulation in online English learning. In addition, learning motivation is critical to self-regulation, as was suggested in the previous research. Its mediating role in the associations between learner beliefs and self-regulation, and between learning anxiety and self-regulation, will also be tested in the present study. 


\section{Past Studies}

\subsection{Self-Regulation in Language Learning}

The concept of self-regulation originally comes from educational psychology, and has recently aroused scholarly interest in second language acquisition (SLA). Basically, self-regulated learning (SRL) involves several basic elements, self-generated thoughts, feelings, strategies and behaviors. All of these should be combined together to facilitate the attainment of goals [22]. The SRL is a cyclic process which is composed of three major phases, namely planning, monitoring and evaluating. From one phase to the next, self-reflection is necessary because it links advanced learners' metacognitive knowledge (what learners know) and self-regulation (what they do and how they prepare for learning). This suggests that reflection is not a fourth phase, separate from other phases in SRL cycle, but automatically happens throughout the SRL process $[23,24]$. In the field of educational psychology, self-regulation in foreign language learning means a self-directive process that language learners adopt to trigger and preserve their cognition, emotions and behaviors so as to attain their specific FL learning goals. Such a self-directive process includes the transformation from the mental abilities of learners to their language learning related skills, which deals with numerous micro-processes that interrelate with each other. Tseng et al. [24] put forward a five-dimensional model to explain English language learners' self-regulatory strategies. Based on previous studies framed in SRL, Tseng et al [24] further proposed that English learners' self-regulation covered commitment control, metacognitive knowledge control, satisfaction control, thoughts and emotions control, and social environment control. The structural relations of the above five dimensions were later confirmed $[25,26]$. Different theoretical models have different definitions of self-regulation, but a number of empirical and theoretical studies have reached a consensus that self-regulation is a multifaceted and socio-educational construct which includes socio-cultural, cognitive, metacognitive, behavioral and self-motivational aspects $[23,27,28]$. Related research also indicated that there were several universal strategies that were commonly adopted to become an expert learner, including rehearsal strategies, elaboration strategies, organizational strategies, comprehension monitoring strategies and affective strategies. These strategies were developed with reflective thinking skills (self-questioning) and required extensive practice accompanied by informative and corrective feedback $[29,30]$.

Past works also suggest that self-regulation was context-specific, which meant that online foreign language learners' self-regulation should be measured accordingly and separately. Regarding the striking differences between the traditional classroom learning environment and a web-based learning environment, online foreign language learners' self-regulation may consist of different variables. Barnard et al. [20] designed a six-factor questionnaire to evaluate English French-as-a-foreign-language learners' online self-regulated learning. The questionnaire included goal setting, time schedule, environmental structure, seeking help, task strategies and personal evaluation. This instrument has been used in many relevant studies, and its validity has been verified in later research [31]. Based on the questionnaire designed by Barnard et al., Zheng et al. [32] later proposed a new questionnaire to assess the online self-regulation of Chinese EFL learners. The questionnaire measured six subscales of online self-regulated English learning, namely goal setting, environment structuring, help seeking, learning strategies, time management and self-evaluation. In the online English learning context, goal setting means developing an action plan specially designed to navigate online English learning towards a clear goal [20]; environment structuring means finding a suitable location for learning English online, such as learning commons in the library [22]; learning strategies refers to the appropriate strategies adopted in order to fulfil online English learning tasks, such as rehearsal strategies, elaboration strategies, organizational strategies, comprehension monitoring strategies and affective strategies [26]; help seeking means the timely asking for help from classmates and teachers when confronted with English learning difficulties via interactive forum [27]; time management means arranging spare time for online English learning so as to guarantee sufficient practice of written English skills [28,29]; self-evaluation means assessing and monitoring online English learning outcomes by learners themselves [33]. 


\subsection{Learner Beliefs and Self-Regulation in Language Learning}

Belief is a complex construct. This complexity makes it hard to define, which is partially attributed to its paradoxical nature and the different agendas of scholars [34,35]. Kalaja and Barcelos [36] defined belief as a form of thought which included certain matters of which people had no previous knowledge but were very confident to act upon, and other matters that were deemed as true for the moment, but may be questioned in future [37]. This definition pointed out the contextual natural of beliefs and also suggested that beliefs were not only a cognitive concept, but also constructs derived from personal experiences and problems. In this sense, studying beliefs means paying special attention to the knowledge that students already have, rather than what they have yet to know [38]. As for language learner beliefs, this concept covers but is not limited to the time required to attain fluency, the language learning difficulties, the appropriate age to start language learning, and the role of grammatical rules, lexical resources and oral communications in the course of language learning. It is always the case that successful language learners have strong and insightful beliefs about foreign language learning. On the one hand, learners' abilities and the application of effective learning strategies will facilitate language learning efficiency. On the other hand, mistaken, uninformed and negative beliefs may result in ineffective learning strategies, negative self-concepts and foreign language learning anxiety [12,13,39]. In particular, Wenden [40] once interviewed 25 English-as-a-second-language (ESL) students about their English learning feelings, also referred to as learners' metacognitive knowledge. Besides language learning strategies, Wenden additionally found that students were able to discuss the following five aspects of language learning: language itself, such as syntax, phonology and vocabulary; their language proficiency; learning progress and difficulties; the learning outcome of specific learning strategies; and their reactions and views on language aptitude, as well as the intrinsic and extrinsic beliefs of learning a foreign language [41].

Horwitz later developed The Beliefs about Language Learning Inventory Questionnaire to measure language learner beliefs $[12,13]$. This questionnaire addressed many issues and controversies pertinent to foreign language learning, and was henceforth commonly adopted in the relevant research. Yang adjusted the questionnaire in order to investigate the relationship between Chinese EFL learner beliefs and their use of learning strategies [12,13]. Yang [38] summarized and identified four subsets of Chinese EFL learner beliefs, including self-efficacy and expectations, perceived value and nature of English, beliefs in foreign language aptitudes and beliefs about formal structural studies. In particular, self-efficacy means personal judgments of language learning competence. When EFL learners think that they have enough language competence to master a certain language skill, they are more willing to exert their efforts. However, they slacken their efforts and even give up when they judge that the ongoing language learning task exceeds their competence [34]. Perceived value and nature of English simply refers to opinions about, personal willingness to, and recognition of learning English [38]. Beliefs on foreign language aptitudes regards foreign language learning as a relatively stable talent, and foreign language learning aptitudes can predict how well individuals can master a foreign language under certain conditions [35]. Beliefs in formal structural studies recognizes grammar and vocabulary as one of the most important parts of foreign language learning, and emphasizes translation, memorization, reading, writing, and corrective feedback in foreign language learning [38].

For the relationship between learner beliefs and self-regulation, Schunk and Ertmer [27] revealed that self-regulation consisted of six dimensions: goal setting, the use of effective learning strategies, the establishment of ideal learning environment, effective time management, seeking help when necessary, and, more importantly, preserving positive beliefs regarding one's capabilities, the anticipated learning difficulties, the values of learning, and the sense of pride, achievement and satisfaction with continuous efforts. In this sense, positive learner beliefs will influence self-regulated learning. According to the social cognitive theory, Bandura [42] and Zimmerman [25] stated that effective self-regulation depended on the sense of self-efficacy in using various learning skills to achieve foreign language proficiency. Meanwhile, self-efficacy used to be the prime subscale of learner beliefs [43]. A learners' efficacy comes from their performances, observational experience, persuasive information, and physical reactions. 
In the context of foreign language learning, students' performances are a reliable predictor to assess self-efficacy. Successful learning outcomes raise efficacy, while failures lower it [43]. Language learners also obtain efficacy by comparing their performances with others. The successes (failures) in foreign language learning cases observed from similar peers raise (lower) their efficacy [27]. The persuasive information obtained from teachers, parents and classmates recognizes learners' capabilities of performing a foreign language learning task [27]. This information may elevate efficacy, but a series of performance failures may lower efficacy [43]. Language learners also obtain self-efficacy from physical reactions, such as sweating and heart rate. The symptoms that reflect greater (less) anxiety indicate a lack (abundance) of language skills. Generally, self-efficacy functions in all phases of self-regulated learning [43].

\subsection{Learning Anxiety and Self-Regulation in Language Learning}

Anxiety is an uncertain and uneasy cognitive state, which represents one of the most well-known and widespread emotions [44]. Since the 1970s, it has become the research focus in foreign language education. There are three mainstreams of anxiety research, namely state anxiety, trait anxiety and situation-specific anxiety [45]. State anxiety presents transitory features and fluctuates over time, while trait anxiety normally remains stable and does not easily change. Among situation-specific anxieties, one of the most prominent studies on foreign language classroom anxiety, which was later developed into a theory of foreign language classrooms, was put forward and led by Horwitz et al. $[12,13,46]$. In their view, foreign language anxiety is to blame for learners' negative emotional reactions in the course of foreign language learning. More importantly, they identified and summarized three subsets that address foreign language classroom anxiety. The three subsets were communication apprehension (worry or fear that something unpleasant may happen in communication), fear of negative evaluation, and test anxiety. In order to measure the classroom anxiety, they designed the questionnaire of Foreign Language Classroom Anxiety Scale (FLCAS). The items exactly correspond to the three subsets [12]. Higher scores indicated greater anxiety in foreign language learning. To be specific, communication apprehension means worries or fears in communicating with teachers and peers, and reflects the level of anxiety triggered by real communication acts [13]; test anxiety refers to a combination of tension, worries, fears of failure that commonly occur during test situations, and a physiological condition triggered by extreme stress or discomfort during and/or before taking a test [46]; fear of negative evaluation is a physiological construct that reflects worries or apprehension about external evaluations, distress from others' negative evaluations and the expectations about others' potential negative evaluations [46].

For anxiety and online learning, Pichette [47] suggested that, since foreign language anxiety makes learners less active, and reluctant to discuss and communicate with their classmates in the classroom, one would naturally think those students would turn to online learning in order to avoid face-to-face interactions with their peers. However, the fact is that there are still certain anxieties, as well as a lack of self-confidence, frequently reported by online language tutors and teachers. From research that investigated the role of tutoring conducted by Burge et al. [48], almost one fifth of respondents expressed their willingness to obtain motivational support, such as positive feedback and encouragement from their tutors. These were even more important than the tutors' profession and knowledge of the course content. As Pichette further pointed out, oral interactions in class accounted for the majority of foreign language learning anxiety. Foreign language courses, no matter whether online or offline, necessarily involve oral interactions among peers. Therefore, online foreign language learning anxiety did not present significant differences from its counterpart in the classroom $[49,50]$. In this respect, the FLCAS developed by Horwitz et al. [46] provided us with a simple way to quantify online foreign language learning anxiety.

For the relationship between anxiety and self-regulation, English learners with a lower level of writing anxiety used more various writing strategies compared to those with higher writing anxiety [45]. One useful conceptual approach to moderate the negative effects of anxiety is self-regulation [18]. 
This involves environment structuring and the allocation of efforts to self-direct the learning process [19]. For instance, students with more self-regulated skills exert substantial efforts and control over their learning environment, while those with self-regulation deficiencies apparently lack such efforts and control. In addition, self-regulated learners are more willing to sustain continuous efforts to decrease distraction. Zimmerman and Schunk [23] associated such self-regulation with the volitional control to stay focused on learning tasks. Besides this, self-regulated efforts are also related with learners' preference for delayed gratification. This self-regulatory strategy is used to obtain higher academic performance. The environmental control mediates the associations between action control and intentions pursuing. For instance, self-regulatory learners favor a learning environment with less distractions, so that they can concentrate on learning tasks. Generally speaking, self-regulated learning skills would effectively moderate the negative effects of anxiety through the use of diverse learning strategies and motivational stimuli $[16,19,50]$.

\subsection{The Mediating role of Learning Motivation}

Motivation generally refers to the psychological force which enables action [51]. For language learning motivation, this is defined as learners' orientation regarding the goal of learning a target foreign language. Ellis regarded motivation as the efforts made and driven by learners' desire or need to learn a foreign language $[6,11]$. The nature of motivation deals with elements such as cognition, feelings, emotions and external environments. Lightbrown and Spada [52] defined foreign language learning motivation as "a complex phenomenon influenced by two major factors: the communicative needs of learners and their attitudes towards the foreign language learning community" [52]. They considered that learners' motivation could be triggered to obtain understanding in their language community once they found it necessary to speak a foreign language in order to communicate or to promote their career. This was in accordance with integrative motivation and instrumental motivation, defined by Gardner and Lambert [53]. In particular, integrative motivation means the desire to join in with the activities of the target foreign language community and develop their language skills [54]. Instrumental motivation is the desire to master a foreign language to seek employment or improve self-education, or improve one's position in a social hierarchy [55]. Besides these, Deci and Ryan [56] found two other types of motivation, namely intrinsic motivation and extrinsic motivation. Intrinsic motivation is driven by personal willingness. Learners feel enjoyment and are willing to learn a foreign language for their own purposes. External motivation usually originates from the expectation of obtaining certain learning outcomes, such as meeting language requirements, obtaining a degree or certificate, or promoting working competence [57]. Zheng et al. [32] developed a questionnaire to investigate Chinese EFL learners' Motivational Self System. This questionnaire consisted of five sub-components. Online English learning experience refers to the previous online language learning experience or foreign language learners' situation-specific motivation in web-based environments [28]; cultural interest is foreign language learners' interest in English cultural products, such as English traditional festivals, soap operas, TV shows or programs, movies, music, artefacts, etc. [29]; integrative motivation reflects the desire to join in the activities of the target foreign language community and develop their language skills; instrumental motivation reflects the desire to master a foreign a language to seek employment, to obtain an academic degree or to improve their position in a social hierarchy [32]; external expectations refers to the expectations from foreign language learners' parents, teachers and peers in terms of their online English learning performance [51].

Self-regulation involves the employment of various sophisticated metacognitive, motivational and behavioral learning strategies. Self-regulated learning is reflected in students' motives for learning, the promising learning outcomes they strive for, and the environmental sources they utilize. In this sense, learning motivation has a close and important relationship with self-regulated learning [33]. Many self-motivational beliefs, such as an interest in English learning and the perceived value of English, are supposed to determine self-regulated strategy use [19,23]. Instrumental motivation is closely associated with learners' social and cognitive engagement, as well as the frequent use of 
self-regulatory skills. Kormos and Csizer [58] posited that stronger instrumental goals were the prerequisite for the employment of effective self-regulated strategies. Learners' cultural interest in English was considered as a significant indicator in predicting and maintaining sustainable learning efforts in second language learning [19]. Zimmerman [23] summarized a cyclic model of self-regulation which consisted of three phases, including the performance phase, self-reflection phase and forethought phase. Each phase has different processes. The performance phase deals with self-control (self-instruction, attentional focusing and task strategies) and self-observation (metacognitive monitoring and self-recording). The self-reflection phase involves self-judgment (self-evaluation and causal attribution) and self-reaction (self-satisfaction and adaptive affect). The forethought phase is divided into task analysis (goal setting and strategic planning) and self-motivation beliefs (self-efficacy, outcome expectations, task value and goal orientation). This cyclic model reveals the correlations between the motivation and self-regulation [58].

\subsection{The Present Study and Hypotheses}

Given that self-regulation is context-specific [18], we focus on academic English writing. Three common learner characteristics, namely motivation, anxiety, and learner beliefs, have consistently been found to be consequential for foreign language learning performance $[7,8]$. Past studies revealed the separate roles of foreign language learning motivation, anxiety and learner beliefs in predicting learners' self-regulation [9,11-13]. Based on the perspective from self-regulation theory, learners' self-generated motivations are the prerequisite for initiating and maintaining learning efforts. As a consequence, learners thus adopt more cognitive and metacognitive strategies to self-regulate their foreign language learning process. The application of those self-regulatory strategies also suppresses the negative effects brought on by learning anxiety $[18,19,23]$. Self-regulation is an effective way to control emotional distress and frustration. From the perspective of social cognitive theory, the learner beliefs of self-efficacy operate in the performance, self-selection and forethought phase of self-regulation [25,28-31].

Despite the clarification of the separate roles of learning motivation, anxiety and learner beliefs on self-regulation, few empirical studies have specifically emphasized their structural relations in either a foreign language learning context (academic English writing at university level in particular) or a web-based environment. More importantly, the mediating role of online learning motivation remains obscure in the associations between learner beliefs and self-regulation, and between learning anxiety and self-regulated learning in an online setting.

Taken together, this study aimed to investigate the relationships amongst online English learner beliefs, online English learning anxiety, online English learning motivation and online self-regulated English learning of Chinese university students. Based on the discussion above, we proposed the hypothesized model in Figure 1. To be specific, we hypothesized that: (1) online English learner belief positively predicted online self-regulated English learning; (2) online English learning anxiety negatively predicted online self-regulated English learning; (3) online English learning motivation mediated the associations between online English learner beliefs and online self-regulated English learning, and between online English learning anxiety and online self-regulated English learning. 


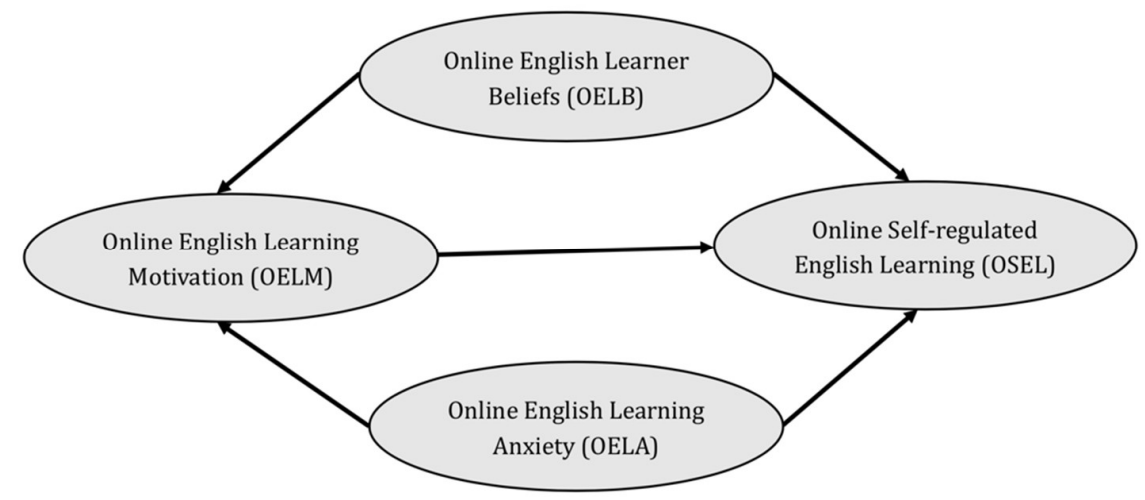

Figure 1. The hypothesized model of relationship amongst online English learner beliefs, online English learning anxiety, online English learning motivation and online self-regulated English learning.

\section{Materials and Methods}

The present study was conducted in an elective academic English writing course at the authors' university for undergraduates during the first semester of the academic year of 2018-2019. This was the first time that the university had put web-based English teaching into practice. The course lasted for two semesters with 18 weeks per semester, and the teaching objective was to develop academic English writing skills for undergraduate students of freshman status. The course included five major modules, namely grammar and punctuation, essay writing, advanced English writing, introduction to research for essay writing and the capstone project. Each teaching module lasted 5-7 weeks. The module learning outcomes were to equip students with the ability to choose appropriate research topics in their related fields and majors, write detailed outlines, find source materials, take and organize useful notes, use proper academic expressions and language, make correct citations in APA format, be aware of and avoid plagiarism, and, finally, to make them better prepared for writing a research paper in the capstone project. The course was a specialization course, offered and delivered by COURSERA, one of the largest MOOCs for online learning. The teaching procedure also included face-to-face instructions and group discussions, as well as corrective comments and feedback (the detailed course information could be found at [59]).

\subsection{Participants}

Participants were 475 first-year undergraduate students successively recruited from the college of computer science and software technology at the authors' university. There were 268 males and 207 females with an average age of $22.6(S D=0.37)$. Most participants majored in computer techniques and software engineering. After examining the log profiles, we found that their online English learning time ranged from 0.5 to 4.5 hours per week, with 164 participants (34.5\%) spending 3.5-4.5 hours per week, 209 participants (44.0\%) spending 1.5-3.5 hours per week, and 102 participants (21.6\%) spending $0-1.5$ hours per week. These suggested that all participants had previous online self-regulated English learning experience.

\subsection{Measures}

The survey items were rated on a seven-point Likert-scale, ranging from $1=$ "strongly disagree" or "not at all true of me" to $7=$ "strongly agree" or "very true of me". They were adapted from previous studies and had good reliability. The overall score (the mean of items) was used in the current analyses. Questions were translated into Chinese, since English was a foreign language for the respondents.

\subsubsection{Online English Learning Motivation}

Online English learning motivation was assessed by the Chinese EFL Learners' Motivational Self-System Questionnaire, a foreign language learning measure developed by You and Dörnyei [15] 
and Zheng et al. [32]. The questionnaire is composed of fifteen items, including five subscales which assess online English learning experience (OELE, three items, e.g., "I enjoy the actual process of online English learning"), cultural interest (CI, three items, e.g., "I like watching English TV programs and talk shows online"), integrative motivation (IM1, three items, e.g., "I will live a meaningful life if I acquire good command of written English"), instrumental motivation (IM2, three items, e.g., "I learn academic English writing online because I want to pass College English Test and obtain my degree"), and external expectations (EE, three items, e.g., "Learning written English online is important because my parents and teachers often emphasize its importance."). Each item was rated on a scale from 1 (not at all true of me) to 7 (very true of me). Higher scores suggested greater online English learning motivation. In the current research, CFA results showed that: $\chi^{2}(16)=97.56, p<0.001$, RMSEA $=0.06$, $\mathrm{SRMR}=0.04, \mathrm{CFI}=0.96, \mathrm{TLI}=0.92$. The overall score (the mean of items) was used in the current analyses. The Cronnbach's $\alpha$ in the assessment of online English learning motivation was 0.75.

\subsubsection{Online English Learning Anxiety}

To assess online English learning anxiety, we revised and adopted the questionnaire in the Foreign Language Classroom Anxiety Scale, initially developed by Horwitz et al. [46]. Since Pichette [47] found that foreign language learning anxieties commonly existed in both classroom teaching and online learning environments, we simply paraphrased the original items in the FLCAS questionnaire to accommodate the research purpose in this study. The current questionnaire consisted of three subscales, including a communication apprehension subscale (CA, five items, e.g., "I feel nervous when I am doing oral reports or writing practice in online English class"), test anxiety scale (TA, three items, e.g., "I feel much pressure to prepare very well in the coming online English writing test"), and fear of negative evaluation subscale (FNE, four items, e.g., "I feel afraid when my online English teacher starts to correct my mistakes"). We deleted two items in the communication apprehension subscale and one item in the fear of negative evaluation subscale, because their factor loadings were lower than 0.5 in the CFA results [48]. All survey items were rated on a seven-point Likert scale. Higher scores suggested greater online English learning anxiety. In the present study, CFA results showed that: $\chi^{2}(7)$ $=32.47, p<0.001, \mathrm{RMSEA}=0.05, \mathrm{SRMR}=0.04, \mathrm{CFI}=0.96, \mathrm{TLI}=0.95$. The resulting nine-item scale had an overall $\alpha$ of 0.86 .

\subsubsection{Online English Learner Beliefs}

Online English learner beliefs were measured with the questionnaire on Beliefs About Language Learning Inventory, first designed by Horwitz $[36,46]$. This questionnaire was used to assess language learner beliefs in offline environment. In the current research, we revised some of these items by emphasizing the web-based environment. The revised questionnaire consisted of four subsets: self-efficacy and expectations of online English learning (SEOEL, three items, e.g., "I am confident that I will write English very well"), perceived value and nature of online English learning (PVNOEL, three items, e.g., "It is important to write correct and idiomatic English"), beliefs in foreign language aptitudes (BFLA, three items, e.g., "People who can write and speak different languages are smarter than others"), and beliefs about foreign language aptitudes (BFSS, three items, e.g., "Learning English grammar and vocabulary is the first step to learn English well"). Each questionnaire item was rated on a scale from 1 (strongly disagree) to 7 (strongly agree). Higher scores suggested stronger online English learner beliefs. In this study, CFA results were: $\chi^{2}(11)=76.52, p<0.001$, RMSEA $=0.05$, SRMR $=0.03$, $\mathrm{CFI}=0.98, \mathrm{TLI}=0.97$. Again, the overall score (the mean of 12 items) was used in the current and subsequent analyses. The Cronnbach's $\alpha$ in the assessment of online English learner beliefs was 0.81 .

\subsubsection{Online Self-Regulated English Learning}

The Chinese version of the Online Self-regulated English Learning Questionnaire was used to assess students' online self-regulation. The questionnaire was initially developed by Zheng et al. [32]. This 18-item questionnaire included six dimensions: setting goals (SG, three items, e.g., "I set daily or 
weekly goals (short-term goals) and even monthly or semester goals (long-term goals) when learning academic English writing online"), creating environment (CE, three items, e.g., "I choose a good location for online academic English learning course to avoid distraction"), learning strategies (LS, three items, e.g., "I will take more comprehensive notes in online academic English writing course than in regular classroom teaching"), seeking help (SH, three items, e.g., "find classmates who are knowledgeable so that I can consult with them if I meet problems or uncertainties in online academic English writing course."), managing time (MT, three items, e.g., "I follow a fixed time schedule to learn online instructional materials about academic English writing and attend the online academic English course."), and self-evaluation (SE, three items, e.g., "I have a regular discussion with my teachers to evaluate my recent online academic English learning performance"). The current study followed the above-mentioned seven-point rating scale, ranging from $1=$ "not at all true of me" to $7=$ "very true of me". Higher scores indicated greater online self-regulated English learning abilities. The CFA results showed that: $\chi^{2}(22)=121.89, p<0.001$, RMSEA $=0.06$, SRMR $=0.05$, CFI $=0.94$, TLI $=0.93$. The resulting eighteen-item scale had overall $\alpha$ of 0.72 .

\subsection{Procedure}

First, this study was approved by the Ethical Committee of the authors' university. Second, electronic informed written consent was obtained before starting the assessment. Third, in order to collect the responses of participants more efficiently, the electronic questionnaires were designed and administered to participants so that they could answer all the questions using their computers or smartphones. The researchers conformed to the same guidelines to administer the assessment. It normally took 10-15 min for students to submit their answers. For this study, we successively recruited 475 fresh undergraduates, which accounted for one third of the total first-year undergraduates. Among the 475 recruited students, 456 finally finished and submitted the online distributed electronic questionnaires. After excluding the invalid questionnaires with incomplete answers, 425 students' responses to the survey were collected and prepared for further analyses.

\subsection{Data Analysis}

Pearson correlations were first conducted to test the relationships among variables. Next, the measurement model was set up through confirmatory factor analysis (CFA) to assess whether observed variables represented their latent variables. We also adopted the following model fit indices, including Chi-square $\left(x^{2}\right)$ goodness of fit, Root Mean Square Error of Approximation (RMSEA), Standardized Root Mean Square Residual (SRMR), Comparative Fit Index (CFI) and Tucker-Lewis Index (TLI). For Chi-square test results, non-significant Chi-square values indicated a good-fit model; for RMSEA, a value smaller than or equal to 0.05 represented good model fit; for SRMR, a value smaller than 0.08 was acceptable; a CFI value or TLI value larger than 0.90 represented an acceptable model fit, according to Schumacker and Lomax, Hu and Bentler and Byrne [60-62].

After establishing the reliability of observed variables towards their latent constructs, we proposed a structural equation model (SEM) to examine the hypothesized relationships among these latent constructs, namely online English learning motivation (OELM), online English learning anxiety (OELA), online English learner beliefs (OELB) and online self-regulated English learning (OSEL).

Specifically, we first tested the effect of English learning anxiety and English learner beliefs (as predictors) on the self-regulation abilities of online learners (as outcome variable). Second, we examined the mediating role of learning motivation in the associations between OELB and OSEL, and OELA and OSEL. Again, we used the same model-fit indices to assess model fit, namely $\chi^{2}$, RMSEA, SRMR, CFI, and TLI. According to Durlak, Cohen's $d$ was used to report the sizes of the effects and indirect effects (small effect $=0.2$, medium effect $=0.5$, large effect $=0.8$ ). Finally, we tested the indirect effects by using bootstrapping and an estimated bias-corrected $95 \%$ confidence interval [63]. Here based on the previous hypotheses, it was assumed that both OELB (beliefs) and OELA (anxiety) had an indirect effect on OSEL (regulation) through OELM (motivation) [64,65]. 
The above-mentioned CFA and SEM analyses were performed by using "lavaan" and "semPlot" packages in R [66-69]. In addition, we used maximum likelihood (FIML) to deal with the missing data, and standardized the latent factor to allow free estimation of all factor loadings. Before running CFA analyses, we used "MVN" packages in R to calculate skewness and kurtosis, in order to examine normality (the distribution of variables), especially for skew and outliers. According to Hair et al. [70], a value of skewness greater than +1 or lower than -1 indicated highly skewed distribution. Likewise, a value of kurtosis greater than +1 indicated too-peaked distribution, and lower than -1 indicated too-flat distribution. Distributions were considered as non-normal if the skewness and kurtosis values exceeded the above guideline [70]. These results were included in the descriptive statistics of preliminary analysis.

\section{Results}

\subsection{Preliminary Analyses}

Table 1 showed the descriptive statistics of the mean scores and standard deviations (SD) of students' responses to the questionnaires $(N=425)$. Cronbach alpha $(\alpha)$ and Omega $(\omega)$ values were above 0.7 , which indicate enough internal consistency reliability. Tables 2 and 3 presented Pearson correlations among the variables. The results indicated that the correlations among all variables were significant at different levels. We also examined the normality of variables with skewness and kurtosis. Most skewness and kurtosis values were within the reasonable range (from -1 to +1 ), which indicated that there were no serious deviations from normality of all variables, according to the criterion proposed by Hair et al. [70] (see Tables 1-3).

Table 1. Descriptive statistics of variables in the study

\begin{tabular}{cccccc}
\hline Variables & Mean & $S D$ & Skewness & Kurtosis & Cronbach's $\alpha /$ Omega $\omega$ \\
\hline OELM. & 4.70 & 1.48 & & & \\
\hline OELE & 4.69 & 1.73 & -0.57 & -0.48 & \\
\hline CI & 4.54 & 1.86 & -0.67 & -0.32 & $0.75 / 0.74$ \\
\hline IM1 & 5.02 & 1.56 & -0.56 & -0.28 & \\
\hline IM2 & 4.98 & 1.62 & -0.64 & -0.32 & \\
\hline EE & 4.27 & 1.50 & -1.32 & 2.62 & \\
\hline OELA & 5.02 & 1.21 & & & \\
\hline CA & 4.89 & 1.63 & -0.44 & -0.81 & $0.86 / 0.85$ \\
\hline TA & 5.10 & 1.35 & -0.55 & -0.28 & \\
\hline FNE & 4.99 & 1.48 & -0.42 & -0.81 & \\
\hline OELB & 5.01 & 1.56 & & & \\
\hline SEOEL & 6.01 & 1.62 & -0.29 & -0.59 & \\
\hline PVNOEL & 4.75 & 1.71 & -0.58 & -0.27 & \\
\hline BFLA & 5.14 & 1.68 & -0.64 & -0.32 & \\
\hline BFSS & 5.15 & 1.74 & -0.37 & -0.68 & \\
\hline OSEL & 4.56 & 1.53 & & & \\
\hline SG & 4.94 & 1.31 & -062 & -0.30 & \\
\hline CE & 4.58 & 1.64 & -0.59 & -0.28 & \\
\hline LS & 4.56 & 1.29 & -1.25 & 2.07 & \\
\hline SH & 5.08 & 1.31 & -0.45 & -0.79 & \\
\hline MT & 4.85 & 1.46 & -0.30 & -0.36 & \\
\hline SE & 4.32 & 1.73 & -0.50 & -0.63 & \\
\hline
\end{tabular}

Notes. OELB, online English learner beliefs; OELM, online English learning motivation; OELA, online English learning anxiety; OSEL, online self-regulated English learning. 
Table 2. Pearson correlations among observed variables of OELM, OELA and OELB (N=425).

\begin{tabular}{|c|c|c|c|c|c|c|c|c|c|c|c|c|}
\hline & 1 & 2 & 3 & 4 & 5 & 6 & 7 & 8 & 9 & 10 & 11 & $\overline{12}$ \\
\hline 1 OELE & - & & & & & & & & & & & \\
\hline $2 \mathrm{CI}$ & $0.37^{b}$ & - & & & & & & & & & & \\
\hline 3 IM1 & $0.32^{b}$ & $0.23^{b}$ & - & & & & & & & & & \\
\hline 4 IM2 & $0.35^{b}$ & $0.30^{\mathrm{b}}$ & $0.33^{b}$ & - & & & & & & & & \\
\hline $5 \mathrm{EE}$ & $0.32^{b}$ & $0.21^{b}$ & $0.24^{\mathrm{b}}$ & $0.38^{b}$ & - & & & & & & & \\
\hline $6 \mathrm{CA}$ & $-0.29^{b}$ & $-0.28^{b}$ & $-0.28^{b}$ & $-0.40^{\mathrm{b}}$ & $-0.18^{b}$ & - & & & & & & \\
\hline $7 \mathrm{TA}$ & $-0.19^{b}$ & $-0.25^{b}$ & $-0.26^{b}$ & $-0.35^{b}$ & $-0.22^{b}$ & $-0.16^{b}$ & - & & & & & \\
\hline 8 FNE & $-0.37^{b}$ & $-0.39^{b}$ & $-0.37^{b}$ & $-0.32^{b}$ & $-0.28^{b}$ & $-0.28^{b}$ & $-0.37^{b}$ & - & & & & \\
\hline 9 SEOEL & $0.46^{\mathrm{b}}$ & $0.25^{b}$ & $0.29^{b}$ & $0.31^{\mathrm{b}}$ & $0.37^{\mathrm{b}}$ & $0.10^{\mathrm{a}}$ & $0.26^{\mathrm{b}}$ & $0.22^{b}$ & - & & & \\
\hline 10 PVN & $0.23^{b}$ & $0.31^{b}$ & $0.40^{b}$ & $0.26^{\mathrm{b}}$ & $0.34^{\mathrm{b}}$ & $0.21^{\mathrm{b}}$ & $0.24^{b}$ & $0.10^{\mathrm{a}}$ & $0.31^{b}$ & - & & \\
\hline 11 BFLA & $0.31^{\mathrm{b}}$ & $0.22^{b}$ & $0.19^{b}$ & $0.37^{\mathrm{b}}$ & $0.26^{\mathrm{b}}$ & $0.16^{b}$ & $0.22^{b}$ & $0.14^{\mathrm{b}}$ & $0.24^{b}$ & $0.38^{b}$ & - & \\
\hline 12 BFSS & $0.22^{b}$ & $0.29^{b}$ & $0.21^{b}$ & $0.40^{\mathrm{b}}$ & $0.17^{\mathrm{b}}$ & $0.09^{a}$ & $0.19^{b}$ & $0.18^{b}$ & $0.28^{b}$ & $0.40^{\mathrm{b}}$ & $0.27^{b}$ & - \\
\hline
\end{tabular}

Notes. ${ }^{\mathrm{a}}$ Correlation is significant at the 0.05 level, ${ }^{\mathrm{b}}$ Correlation is significant at the 0.01 level. "OELE, CI, IM1, IM2, EE" (measures of online English learning motivation, OELM, in white); “CA, TA, FNE" (measures of online English learning anxiety, OELA, in light grey); "SEO, PVN, BFL, BFS" (measures of online English learner beliefs, OELB, in dark grey).

Table 3. Pearson correlations between OELM and OSEL, OELA and OSEL, and OELB and OSEL $(\mathrm{N}=425)$.

\begin{tabular}{lllllllllllll}
\hline & OELE & CI & IM1 & IM2 & EE & CA & TA & FNE & SEO & PVN & BFL & BFS \\
\hline $13 \mathrm{SG}$ & $0.26^{\mathrm{b}}$ & $0.20^{\mathrm{b}}$ & $0.19^{\mathrm{b}}$ & $0.24^{\mathrm{b}}$ & $0.33^{\mathrm{b}}$ & $-0.10^{\mathrm{a}}$ & $-0.17^{\mathrm{b}}$ & $-0.26^{\mathrm{b}}$ & $0.28^{\mathrm{b}}$ & $0.39^{\mathrm{b}}$ & $0.11^{\mathrm{a}}$ & $0.10^{\mathrm{a}}$ \\
$14 \mathrm{CE}$ & $0.34^{\mathrm{b}}$ & $0.28^{\mathrm{b}}$ & $0.30^{\mathrm{b}}$ & $0.22^{\mathrm{b}}$ & $0.41^{\mathrm{b}}$ & $-0.19^{\mathrm{b}}$ & $-0.26^{\mathrm{b}}$ & $-0.29^{\mathrm{b}}$ & $0.33^{\mathrm{b}}$ & $0.28^{\mathrm{b}}$ & $0.20^{\mathrm{b}}$ & $0.25^{\mathrm{b}}$ \\
$15 \mathrm{LS}$ & $0.42^{\mathrm{b}}$ & $0.31^{\mathrm{b}}$ & $0.29^{\mathrm{b}}$ & $0.33^{\mathrm{b}}$ & $0.22^{\mathrm{b}}$ & $-0.20^{\mathrm{b}}$ & $-0.23^{\mathrm{b}}$ & $-0.35^{\mathrm{b}}$ & $0.29^{\mathrm{b}}$ & $0.26^{\mathrm{b}}$ & $0.33^{\mathrm{b}}$ & $0.32^{\mathrm{b}}$ \\
$16 \mathrm{SH}$ & $0.25^{\mathrm{b}}$ & $0.27^{\mathrm{b}}$ & $0.26^{\mathrm{b}}$ & $0.41^{\mathrm{b}}$ & $0.28^{\mathrm{b}}$ & $-0.37^{\mathrm{b}}$ & $-0.28^{\mathrm{b}}$ & $-0.30^{\mathrm{b}}$ & $0.28^{\mathrm{b}}$ & $0.32^{\mathrm{b}}$ & $0.38^{\mathrm{b}}$ & $0.31^{\mathrm{b}}$ \\
$17 \mathrm{MT}$ & $0.21^{\mathrm{b}}$ & $0.35^{\mathrm{b}}$ & $0.19^{\mathrm{b}}$ & $0.26^{\mathrm{b}}$ & $0.24^{\mathrm{b}}$ & $-0.46^{\mathrm{b}}$ & $-0.21^{\mathrm{b}}$ & $-0.22^{\mathrm{b}}$ & $0.26^{\mathrm{b}}$ & $0.21^{\mathrm{b}}$ & $0.22^{\mathrm{b}}$ & $0.28^{\mathrm{b}}$ \\
$18 \mathrm{SE}$ & $0.39^{\mathrm{b}}$ & $0.42^{\mathrm{b}}$ & $0.23^{\mathrm{b}}$ & $0.37^{\mathrm{b}}$ & $0.29^{\mathrm{b}}$ & $-0.08^{\mathrm{a}}$ & $-0.29^{\mathrm{b}}$ & $-0.23^{\mathrm{b}}$ & $0.19^{\mathrm{b}}$ & $0.28^{\mathrm{b}}$ & $0.17^{\mathrm{b}}$ & $0.29^{\mathrm{b}}$ \\
\hline
\end{tabular}

Notes. ${ }^{\text {a }}$ Correlation is significant at the 0.05 level, ${ }^{\mathrm{b}}$ Correlation is significant at the 0.01 level. "OELE, CI, IM1, IM2, EE" (measures of online English learning motivation, OELM, in bold and white); "CA, TA, FNE" (measures of online English learning anxiety, OELA, in bold and light grey); "SEO, PVN, BFL, BFS" (measures of online English learner beliefs, OELB, in bold and dark grey); "SG, CE, LS, SH, MT, SE" (measures of online self-regulated English learning, OSEL.

To test the impact of gender difference on each latent factor, Welch's Test for Unequal Variances (also called Welch's $t$-test) was conducted subsequently. The difference tests suggested that female students reported higher online English learning motivation that male students, $M_{\text {Females }}=4.67, M_{\text {Males }}=4.38$, $t=3.39, p<0.001$. Therefore, gender was included as a covariate for online English learning motivation. As for age, since all participants aged from 21 to 24 and generally belong to the same age group, we did not specially control the impacts of age on latent factors in the subsequent analyses.

\subsection{Measurement Model}

The measurement model was composed of four latent factors (online English learning motivation, online English learning anxiety, online English learner beliefs and online self-regulated English learning) and 18 observed variables in total. The results of the measurement model indicated good model fit to the data despite the significance of Chi-square result, $\chi^{2}(147)=387.62, p<0.001$, RMSEA $=0.06$, $\mathrm{SRMR}=0.05, \mathrm{CFI}=0.96, \mathrm{TLI}=0.95$, which were in accord with the cutoff model-fit criteria proposed by Schumacker and Lomax, Hu and Bentler and Byrne [60-62]. The loadings (standardized coefficients, $\beta$ ) ranged from 0.61 to 0.93 , and the lowest standardized loading was 0.61 for an observed variable of OSEL. Taken together, the above suggested that the measurement model in the present study had a reasonable factor structure and sufficient convergent validity (see Table 4). Mean scores for each latent factor were calculated for testing the hypothesized structural model. 
Table 4. Results for the measurement model $(\mathrm{N}=425)$.

\begin{tabular}{|c|c|c|c|c|}
\hline Latent Construct & Observed Variables & Estimate & $S E$ & $\beta$ \\
\hline \multirow{5}{*}{$\begin{array}{l}\text { Online English Learning } \\
\text { Motivation (OELM) }\end{array}$} & $\begin{array}{l}\text { Online English learning experience } \\
\text { (OELE) }\end{array}$ & 0.829 & 0.082 & $0.76^{* * *}$ \\
\hline & Cultural interest (CI) & 0.874 & 0.076 & $0.78^{* * *}$ \\
\hline & Integrative motivation (IM1) & 0.905 & 0.058 & $0.80^{* * *}$ \\
\hline & Instrumental motivation (IM2) & 0.913 & 0.052 & $0.83^{* * *}$ \\
\hline & External expectations (EE) & 0.736 & 0.073 & $0.72 * * *$ \\
\hline \multirow{3}{*}{$\begin{array}{l}\text { Online English Learning } \\
\text { Anxiety (OELA) }\end{array}$} & Communication apprehension (CA) & 0.982 & 0.052 & $0.85^{* * *}$ \\
\hline & Test anxiety (TA) & 0.990 & 0.048 & $0.86^{* * *}$ \\
\hline & Fear of negative evaluation (FNE) & 1.121 & 0.039 & $0.88^{* * *}$ \\
\hline \multirow{4}{*}{$\begin{array}{l}\text { Online English Learner } \\
\text { Beliefs (OELB) }\end{array}$} & $\begin{array}{l}\text { Self-efficacy and expectations of } \\
\text { online English learning (SEOEL) }\end{array}$ & 1.157 & 0.025 & $0.93^{* * *}$ \\
\hline & $\begin{array}{l}\text { Perceived value and nature of online } \\
\text { English learning (PVNOEL) }\end{array}$ & 1.110 & 0.029 & $0.90^{* * *}$ \\
\hline & $\begin{array}{c}\text { Beliefs about foreign language } \\
\text { aptitudes (BFLA) }\end{array}$ & 0.876 & 0.068 & $0.79^{* * *}$ \\
\hline & $\begin{array}{l}\text { Beliefs in formal structural studies } \\
\text { (BFSS) }\end{array}$ & 0.839 & 0.072 & $0.76^{* * *}$ \\
\hline \multirow{6}{*}{$\begin{array}{l}\text { Online Self-regulated } \\
\text { English Learning (OSEL) }\end{array}$} & Setting goals (SG) & 0.720 & 0.093 & $0.68^{* * *}$ \\
\hline & Creating environment (CE) & 0.687 & 0.087 & $0.63^{* * *}$ \\
\hline & Learning strategies (LS) & 0.758 & 0.069 & $0.72^{* * *}$ \\
\hline & Seeking help (SH) & 0.732 & 0.072 & $0.70^{* * *}$ \\
\hline & Managing time (MT) & 0.632 & 0.091 & $0.61^{* * *}$ \\
\hline & Self-evaluation (SE) & 0.680 & 0.082 & $0.67^{* * *}$ \\
\hline
\end{tabular}

\subsection{Testing the Hypothesized Model}

Based on the previous hypothesis and Pearson correlation results, we conducted structural equation model analysis with online English learner beliefs and online English learning anxiety as predictors, online English learning motivation as a mediator, and online self-regulated English learning abilities as an outcome variable.

According to the procedure of mediating effect analysis recommended by Wen and Ye [64], we firstly analyzed the direct effects of English learner beliefs and learning anxiety on their self-regulation abilities in a web-based environment. Results showed that online English learner beliefs $(\beta=0.25$, $p<0.01)$ and learning anxiety $(\beta=-0.20, p<0.01)$ significantly predicted their online self-regulated English learning abilities.

Next, we tested the mediating role of online English learning motivation in the links between online English learner beliefs and online self-regulated English learning, and between online English learning anxiety and online self-regulated English learning (see Figure 2). Though the Chi-square result was significant, CFI, TLI, SRMR and RMSEA were consistent with the cutoff model-fit criteria $\left(\chi^{2}(4)=27.86, p<0.001\right.$, RMSEA $=0.05$, SRMR $\left.=0.04, \mathrm{CFI}=0.97, \mathrm{TLI}=0.95\right)$, according to $\mathrm{Hu}$ and Bentler [60]. Results showed that online English learner beliefs $(\beta=0.31, p<0.01)$ positively predicted online English learning motivation. In contrast, online English learning anxiety $(\beta=-0.29, p<0.01)$ negatively predicted online English learning motivation. 


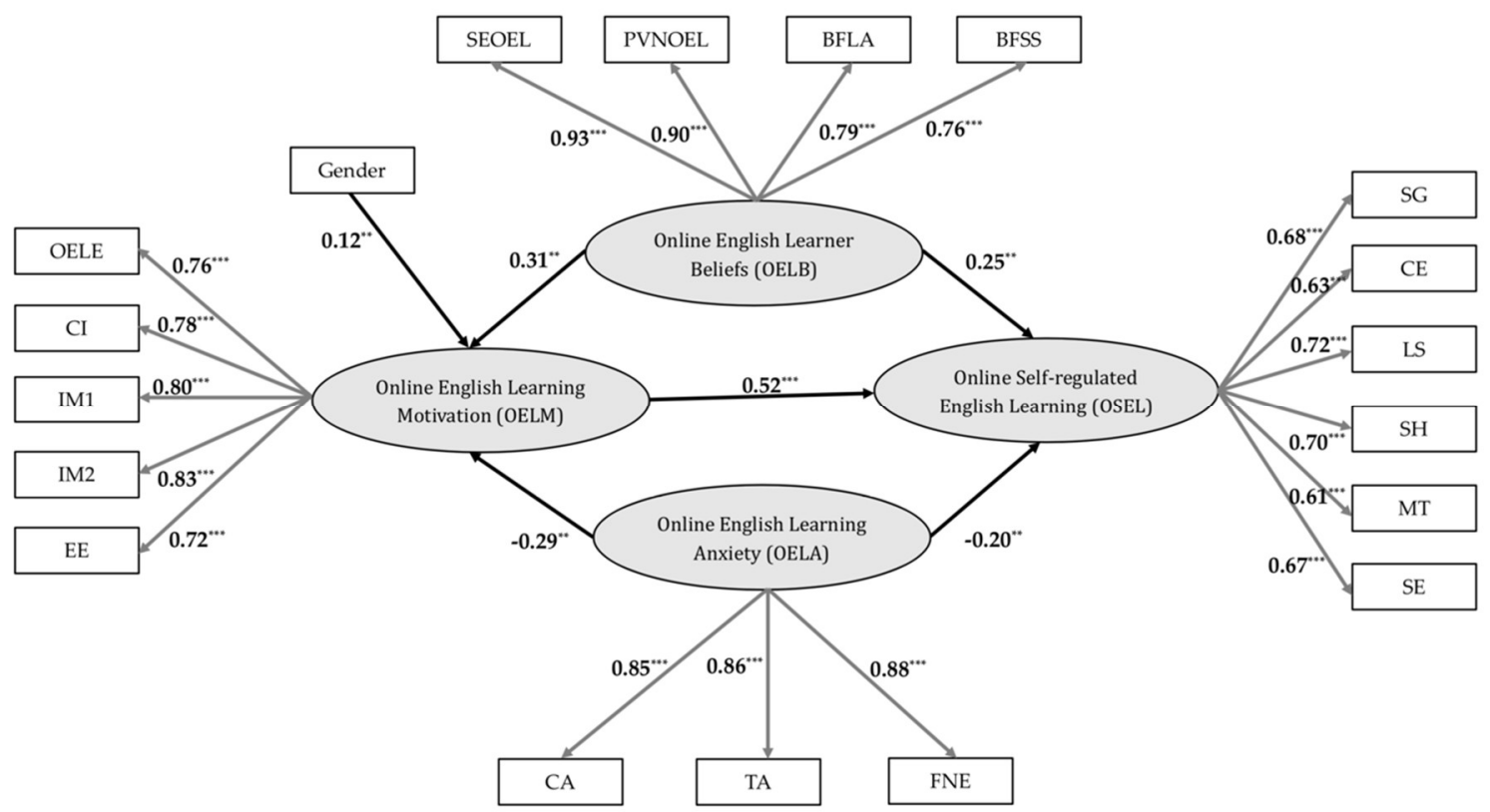

Figure 2. Structural model of the associations among online English learning motivation, online English learning anxiety, online English learner beliefs and online self-regulated English learning. ${ }^{*} p<0.05$, ** $p<0.01,{ }^{* * *} p<0.001$.

Finally, the bootstrapping and an estimated bias-corrected 95\% confidence interval were used to test the significance of the above mediating effects, according to Preacher and Hayes [65]. Results showed that, after controlling for gender, the mediating effect ( $95 \%$ confidence interval) on the association between online English learner beliefs and online self-regulated English learning was $(0.226, p<0.001$, $95 \%$ CI: $[0.156,0.313])$, and the mediating effect (95\% confidence interval) on the association between online English learning anxiety and online self-regulated English learning was $(0.166, p<0.001,95 \%$ CI: $[0.093,0.268])$. Table 5 showed that the two $95 \%$ confidence intervals did not include zero, which indicated the significant mediating role of online English learning motivation in both associations. Taken together, the results indicated that online English learning motivation mediated the associations between online English learner beliefs and online self-regulated English learning, and between online English learning anxiety and online self-regulated English learning.

Table 5. Path coefficients of the model.

\begin{tabular}{lllllllll}
\hline & Path & & & $\begin{array}{c}\text { Estimated } \\
\text { Effect }\end{array}$ & SE & 95\% CI & $p$ & Cohen's $d$ \\
\hline OELB $\rightarrow$ & OELM $\rightarrow$ & OSEL & 0.226 & 0.038 & {$[0.156,0.313]$} & $<0.001$ & 0.28 \\
\hline OELA $\rightarrow$ & OELM $\rightarrow$ & OSEL & 0.166 & 0.041 & {$[0.093,0.268]$} & $<0.001$ & 0.43 \\
\hline
\end{tabular}

Notes. OELB, online English learning beliefs; OELM, online English learning motivation; OELA, online English learning anxiety; OSEL, online self-regulated English learning.

\section{Discussion}

Self-regulation is critical in online English learning because it incorporates self-directive processes and self-beliefs and facilitates the transformation of learners' mental abilities into academic performance skills, such as English writing for academic purpose [18,19,23]. Drawing upon past studies on online self-regulation, we tested the effects of online English learner beliefs and online English learning anxiety on online self-regulated English learning. Our results showed that learner beliefs positively predicted self-regulated English learning, while learning anxiety negatively predicted self-regulated English learning in web-based environment. In addition, online English learning motivation was a mediator in the above-mentioned associations. The findings suggested that stronger learner beliefs, 
such as self-efficacy and the perceived value of learning English, were beneficial to enhancing learning motivation and self-regulation. In contrast, higher learning anxiety, such as text anxiety and fear of negative evaluation, did harm to learners' motivation and their self-regulated learning.

\subsection{The Effect of Online English Learner Beliefs on Online Self-regulated English Learning}

As expected, the present study found that online English learner beliefs positively predicted online self-regulated English learning. This meant that learners with stronger beliefs put greater effort into the employment of self-regulatory skills, which lent support to the social cognitive theory [42,71]. In particular, the learner belief of self-efficacy and the perceived value of English learning operates in all phases of self-regulation, including performance, self-selection and forethought. As pointed out by Zaykovskaya et al. [72], learner beliefs were commonly regarded as a critical component in foreign language learning because they largely determined how learners perceive the English language, the English-speaking community and the process of English learning. This also applied to Chinese EFL learners.

As the primary observed variable defined in the construct of online English learner beliefs, self-efficacy is the belief that language learners possess in their individual abilities. These abilities specially refer to those aimed at overcoming challenges and successfully completing English learning tasks [27,43]. Learners' self-efficacy and expectations of online English learning are likely to influence their emotional reactions [43]. Learners with higher self-efficacy and expectations normally express more positive reactions towards online English learning, and enjoy the online English learning process. Conceptually, self-efficacy is related with self-regulation because they share many similarities, since they both involve self-control and the ability to modulate English learners' behavior to realize their goals. The research findings in this paper also corroborate their relationship. The increasing level of self-efficacy enables students to be more confident and active to set their goals and make plans [27-30]. Online English learners may more frequently adopt various learning strategies to fulfil their specific English learning objectives. Learning strategies may include rehearsal strategies, elaboration strategies, organizational strategies, comprehension-monitoring strategies and affective strategies $[34,35]$. Online English learners also have the flexibility to decide at what time to shift from one strategy to another, as they generally self-monitor their learning pace. Similarly, self-efficacy and online English learning are empirically entwined. Self-efficacy depends on personal beliefs in one's own capability to overcome learning difficulties. The online English learners with higher levels of self-efficacy are normally highly motivated, while those with lower levels of self-efficacy are often less motivated [36,37]. In this sense, it is easy to understand the reasons that self-efficacy is also positively correlated with help-seeking and self-evaluation. In detail, English learners with strong self-efficacy more easily develop instrumental help-seeking, which plays a key role in English learning [38,39]. Meanwhile, self-efficacy also fosters adaptive help-seeking behaviors which depend on individual insight and recognition to solve the problems that may appear during the online English learning process. For example, we found that online English learners with a higher self-efficacy are usually more proactive in peer assessments, in which they utilize to share their skills and experience, as well as answering problems in grammar, phrase or expressions. Besides, self-efficacy also encourages and motivates students to review their current English learning progress in a timely fashion, in order to distinguish what has been improved and what still requires further improvements $[18,19,23,39]$. This gives them motivational advantages in developing the efficient time management and self-evaluation skills prescribed in online self-regulated English learning.

Second, as for the perceived value and nature of online English learning, the students commonly believe in the importance and strengths of English writing and express a strong willingness to learn English writing. Similar to self-efficacy and expectations, the consensus on and higher level of recognition of academic English writing flourishes students' willingness to foster their self-directed skills and actively engage themselves in online learning. In particular, learners who highly recognize the values of English learning are always proactive in goal-setting, making plans, adopting self-monitoring 
and help-seeking strategies, managing time schedule and doing self-evaluation. Those with a perceived nature of learning written English are often driven by integrative motivation or instrumental motivation, which in turn correlates with the above-mentioned factors in online self-regulated English construct $[25,28]$. Integrative and instrumental motivation provide a strong impetus for learners to foster their self-regulated English learning abilities. For example, students with higher perceived values of English are more eager and curious to learn new written English skills, which encourages them to update their goals constantly. This suggests the mediating role of motivation, which will be further discussed in the subsequent sections [29]. Besides this, such students hold moderate attitudes towards negative comments and feedback from teachers and classmates. More importantly, the learners who have perceived the value and nature of online English learning also recognize the importance of self-evaluation [30]. Frequent self-assessment enables students to reflect on the academic English written skills they have acquired, and the new English writing skills they need to learn in the next stage. During the self-assessment, learners can establish broader objectives, such as motivations for English learning, classroom attitudes, classroom environment, general grammar and vocabulary and cultural understanding [31-33].

Third, foreign language aptitudes (FLA) account for a commonly observed phenomenon where some students quickly learn a foreign language with greater ease and often obtain a better FL learning performance than others. FLA is also regarded as a relatively stable talent which varies from person to person. In the current research, those with higher English aptitudes are more self-regulated, and vice versa. This is because English aptitudes endow online English learners with the confidence and motivation needed to positively transform their mental skills into language skills [31,43]. For example, in the planning stage, online English learners with strong English aptitudes are more capable of meeting goals and standards within the span of specific tasks, sessions or courses in different phases. They present a clear perception of the learning environment. In the performance stage, they are highly committed to their English learning experience, and compare their English learning progress with the goals they set in the previous stage. In the reflection stage, the students presenting higher language aptitudes are greatly motivated to review and assess their learning experience, including corrective feedback, and mentally storing ideas and concepts that are useful for future online English learning $[25,33]$. Beliefs about formal structural studies (BFSS) may arouse learners of the proper form, or may indicate the successive emphasis on empty form. There are three levels of formality in English. The most formal English is generally observed in textbooks, official reports, academic papers, commercial contracts, and recommendation letters. A formal English expression should consider punctuation, grammar and appropriate sentence structure. In the current study, the observed variable of beliefs in English formal structural studies significantly positively correlates with the observed variables in the theoretical construct of online self-regulated English learning. It is deduced that the mastery of English formal structures is challenging, and thus requires great effort and motivation. Learners with a strong BFSS are normally highly motivated to improve their English proficiency. Again, the learning motivation acts as a mediating agent to transfer BFSS into self-regulated ability, here referring to goal setting, time management, help seeking, structure environment and self-evaluation [28-33].

\subsection{The Effect of Online English Learning Anxiety on Online Self-regulated English Learning}

The findings in the present study were in accordance with the previous research. On the one hand, foreign language anxiety was a context-specific anxiety that arose when students were learning or using a second language. The source of foreign language learning anxiety originated from the imbalance between learners limited English language proficiency and their desire to truly express themselves. This applied in both offline and online environments, as argued by Horwitz [12,13,46]. On the other hand, online English learning anxiety negatively predicted online self-regulated English learning. This means that learners with greater (less) anxiety spend less (more) effort to deploy self-regulatory skills. This supported the statement that learning anxiety is negatively associated with the use of cognitive strategies, such as rehearsal, elaboration and metacognition [12]. As a result, 
students might negatively evaluate their academic performance, slacken their efforts in goal setting and time management, and devalue necessary learning outcomes [13].

First, communication apprehension negatively correlated with goal setting. Goal setting has been a powerful process for thinking about the ideal English learning outcomes, and for motivating students to precisely understand what they want to achieve and concentrate on their efforts, while an increased level of communication apprehension means a less active action plan towards a goal of acquiring specific language skills, since goal setting plays a determinant role in the personal development and management literature $[18,44]$. It is deduced that goal setting should consider both achievement and failure. Foreign language learners are also encouraged to set achievable goals in a simple and repetitive route towards a larger goal, even a more ambitious one. However, a higher level of test anxiety will result in poor foreign language learning performance, as previously discussed, and demonstrated by various studies $[20,45]$. In this respect, it is understandable that the increasing test anxiety may break the balance between achievement and failure, and the failure times would outweigh the achievements. Thus, English learners will be less motivated to set goals regarding the further development of their English skills. Similar analyses also apply when explaining its (communication apprehension) negative prediction on environment structuring, task strategies, help seeking, time management and self-evaluation. The general reason for this is that an increase in communication apprehension will greatly undermine personal willingness to deploy diverse cognitive strategies [24]. Students may find it difficult to build up their instructional setting in an online English class, and easily lose their momentum for English learning because they find it difficult to follow teachers' instructions. Moreover, help seeking involves a series of predictable and purposeful cognitive and behavioral procedures, with each yielding specific solutions [22,46]. However, the increased worries may hinder the process of finding or receiving support from others in an efficient manner. This also disturbs time management efficiency, since students may spend more time struggling to seek assistance to solve the problems they encounter in online English learning. In addition, student self-evaluation, or self-assessment, involves students in assessing their work and English learning progress. Through self-evaluation, students can identify their weak points, and skill gaps in English knowledge where they need to focus on their attention. Self-evaluation also allows students to set realistic goals, adjust their working direction, track their English learning progress and decide when to step into the learning phase $[25,26,47]$. Overall, this process motivates and encourages learners' self-reflection and responsibility for their online English learning. However, the increasing level of anxiety will suppress the mediating agents of self-motivation. The less-motivated students will lack the confidence to learn English well, and thereby be unwilling to put additional effort into self-assessment and its related strategies, such as self-reflection and self-monitoring. For instance, an effective self-evaluation may be paired with peer assessment, which will serve as a valuable tool in actively promoting foreign language learners' language competence.

Second, test anxiety was also negatively associated with online self-regulated English learning abilities. Test anxiety refers to a psychological condition where people undergo extreme distress and anxiety in testing conditions. Its symptoms can be physical, behavioral, cognitive and emotional. For example, severe test anxiety may result in increasing drop-out rates in the online English courses. Many learners report an empty mind when answering the test even if they are well prepared for the test and know the answers $[28,50]$. They are occasionally stuck in negative self-talk, have trouble focusing on the test and are easily distracted from their in-processing routine. Their emotional symptoms are also common to observe, such as low self-esteem, anger and a sense of hopelessness and feelings of helplessness in reversing the sense of adversity in English writing tests. These symptoms of anxiety can be traced back to learners' previous poor testing outcomes due to lack of preparation and fear of failure. In particular, the findings suggest that test anxiety disturbs students' use of cognitive strategies, such as goal setting. The increased test anxiety may impair cognition by misleading students into setting unrealistic goals [28-30].

Third, the fear of negative evaluation was negatively correlated with online self-regulated English learning in web-based environment. In general, fear of negative evaluation is a psychological construct 
that not only reflects learners' distress over negative evaluations by their teachers and classmates, but also the expectation and apprehension that others will negatively evaluate them [47]. In the current case, it turns out that fear of negative evaluation is negatively associated with all the measured variables in online self-regulated English learning constructs, especially for goal setting, time management, environment structuring and the deployment of various learning strategies. These affected variables are closely related to the self-monitoring strategies and affective strategies adopted by the learners during the English course. To be more specific, self-monitoring is a concept that evaluates students' self-presentations, expressive behaviors and non-verbal affective displays. It is often regarded as a personality trait that formulates the ability to regulate personal behavior in order to accommodate diverse social situations. Meanwhile, affective strategies are concerned with the management of positive and negative emotions. Generally speaking, positive affective environments facilitate English learning, while negative affective environments impedes English learning [31-33,44,45]. Both self-monitoring and affective strategies are in active use when anxiety remains at a lower level. The self-monitoring process is internal and driven by intrinsic motivation, but the self-generated reflections from the self-monitoring process are not exempt from external influence. Once foreign language learners obtain unsatisfying grades, their anxiety level dramatically increases as they may treat the poor grades as negative evaluations, which would, in turn, increase students' anxiety levels in the next exam [73].

\subsection{The Mediating Role of Online English Learning Motivation}

As expected, one major finding in this study supported the belief that online English learning motivation mediated the association between online English learner beliefs and online self-regulated English learning $[18,19,36,74,75]$. To be specific, learner beliefs appeared to facilitate online English learning motivation; at the same time, students' online English learning motivation promoted their online self-regulated English learning. Another major finding revealed that the association between learning anxiety and online self-regulated English learning is mediated by online English learning motivation. Different types of anxiety negatively predicted learning motivation, which meant that increased anxiety demotivated learners; as a consequence, lower motivation, in turn, suppressed self-regulation.

For the relationship between online English learner beliefs and learning motivation, the learner beliefs of self-efficacy and expectations are the driving force for improving learning motivation and a sense of accomplishment [34-37,53,54]. Regardless of the forms of motivational factors, they are deeply rooted in the core belief of learners that learning outcomes originate from real actions, and the emerging learning difficulties will easily demotivate them and lessen the incentive to take action [55]. Self-efficacy beliefs penetrate people's daily life, concerning their productive or self-debilitating thinking, their degree of motivation and perseverance when faced with difficulties, their vulnerability in the face of stress and depression, and their diverse life choices. People with strong self-efficacy beliefs treat difficult learning tasks as challenges rather than threats. They normally have greater intrinsic interest, motivation and deep engrossment in goal-oriented activities and preserve a higher level of commitment to their activities [53,54]. Meanwhile, greater self-efficacy also cultivates feelings of serenity when handling challenging tasks and activities in the learning process. Therefore, self-efficacy serves as a powerful predictor of the level of accomplishment that one ultimately envisions and achieves [58]. As argued by Kormos et al. [76], based on their interactive model of language learning motivation, the language learning goals, personal attitudes and beliefs and parental expectations and encouragement significantly predicts learners' motivations in second language or foreign language learning [76]. This model supports the importance of self-regulated beliefs in FL learning motivation. The future self-efficacy and expectations that are externally and internally mediated will differently interact with motivated behaviors in terms of language learners from different groups. The belief in English as a universal language also plays an important role in persuading students to sustain their learning efforts. Such beliefs vary accordingly based on the English prominence in different international communities $[14,15,77]$. It is also posited that the external factors that originate from the 
immediate social environment of learners, such as family and schools, have a differentiated effect on foreign language learning goals, attitudes and future self-guides, the core components of learning motivation. These external factors are directly related to motivated behaviors that greatly influence learning efforts and persistence in foreign language learning. As a consequence, learners situate themselves in a dynamic system related to their social, cultural and external factors that directly influences the core components of learners' intrinsic learning motivation [34-36,78].

For the relationship between online English learning anxiety and online English learning motivation, the findings in the present study were consistent with the previous research. Students with lower foreign language learning anxiety were more motivated in online English learning, while those with higher foreign language learning anxiety were less motivated to learn English in a web-based environment [79-81]. Once faced with anxiety, learners' cognition, emotions and behaviors are seriously affected [79]. Under these conditions, they are more sensitive to failures. The environmentally induced anxieties may distract students from acquiring academic English written skills, and put greater emphasis on test results. This results in the fear of negative evaluation that unconsciously suppresses learners' intrinsic motivation. In contrast, students with lower anxiety normally possess positive learning attitudes, greater self-efficacy and expectations, and a higher perceived value of English [80,81]. These directly promote learners' motivation. Overall, the communication apprehension, test anxiety and fear of negative evaluation would demotivate online English learners to become self-reliant. In this sense, an increasing level of anxiety will suppress the mediating agent of self-motivation. The less-motivated students would lack the confidence and willingness to actively deploy diverse self-regulated strategies, namely goal setting, time management, environment structuring, help seeking, and self-evaluation. These findings are consistent with Corell and Clark, Thompson and Lee and Martirossian and Hartoonian [49,50,82].

For the relationship between online English learning motivation and online self-regulated English learning, from the perspective of the social cognitive theory, self-regulation is viewed as both a personally directed form of learning and a social form of learning, such as goal setting and help seeking [42,71]. The proactive qualities of personal initiative, perseverance and adaptive skills are prerequisites for activating self-regulation. The source of these proactive qualities comes from advantageous motivational beliefs and metacognitive strategies $[14,15,26]$. To be specific, online English learners with previous online English learning experience (OELE) are more inclined to foster self-regulated abilities and to become an ideal self-regulated learner. This means that learners with more OELE experience tend to more positively deploy the above self-regulated strategies, while learners with more OELE experience are more likely to follow the aforementioned strategies, especially in seeking help, self-evaluation, goal setting, planning awareness and self-monitoring and environment structuring. Our finding contradicted with Zheng et al. [32]. Next, cultural interest is also correlated with online self-regulated English learning (OSEL) $[18,19,23]$. Cultural interest not only involves material heritage, but also touches on intangible cultural heritage, including but not limited to English language and English-related festivals, music, arts, poetry, classics, religion, literature, values and justice. The learners with a stronger cultural interest are highly self-motivated and more likely to sustain their learning efforts [28]. This empowers them with advantages in goal setting, planning, self-monitoring and time management. Meanwhile, the intrinsic interest driven by English cultures constantly encourages students to deploy various learning strategies to promote their English learning performance [75]. Third, instrumental motivation is related to instrumentality-prevention. Learners perceive and acknowledge the duties and obligations of English learning as the means to an end, such as passing English exams. This is commonly observed from new college undergraduates, since they eagerly want to fulfil the minimum college English requirement so as to obtain their degree [28,32]. Goal-oriented is one prominent feature of instrumental motivation. Learners driven by instrumental motivation may be stuck in regular routines and focus on expanding, reaching and growing. It is common to discuss instrumental motivation together with integrative motivation that proposes instrumentality promotion. Integrative motivated learners always feel obliged to attain higher English proficiency so that they 
can have a deeper understanding of English native speakers and achieve a better future self [51,58]. Integrative motivation has proven to be a strong stimulation and impetus in English as a second language or foreign language learning context. In the current case, both integrative and instrumental motivation are correlated with online self-regulated English learning abilities. The above-mentioned results also lend support to the arguments of Kormos and Csizer [58,76] that instrumental motivation is a positive predictor of learners' English learning efforts, which may affect self-regulated learning efficiency and strategy use (including, but not limited to, rehearsal strategies, elaboration strategies, organizational strategies, comprehension monitoring strategies and affective strategies) in the three main stages of planning, performing and reflecting. The possible reasons for this are that Chinese EFL learners are heavily dependent on instrumental motivation because English is the mandatory subject for large-scale and high-stake tests, such as 'Gaokao', the national higher education entrance examination, and CET4 or CET6 $[83,84]$. So, students and their mediating agents (parents and teachers) commonly believe that the proficient use of English plays a key role in their future career success. Since instrumental motivation is goal-oriented, online English learners more frequently check on their updated progress and flexibly adjust their task strategies. Their learning objectives are very specific and they are more willing to invest more effort in online self-regulated learning, in order to achieve a better academic performance, or obtain a better job with a higher salary. Beyond social obligations or economic pursuit, more and more learners may encompass and realize their personal development and self-actualization during the course of English learning [29-31]. The above discussion suggests that both integrative and instrumental motivation are needed in online English learning and fostering self-regulated abilities. Fourth, external expectations are also significantly correlated with the self-regulation of online English learners. The findings are consistent with Zheng et al., Liu and Huang, and Hao et al. [32,78,79]. Though the physical separation from parents allows university students to be gradually adapted into a more flexible time management pattern and autonomous learning mode, university students' social obligations, derived from teacher and parental expectations, are still strong and may not significantly decrease as they start the second-year undergraduate study $[38,45,84]$. Such evidence supports the current case, where external expectations from learners' parents and teachers play a key role in influencing self-regulated abilities. The reasons for this can be traced back to the role of expectations from parents and teachers in stimulating instrumental motivation. As discussed, instrumental motivation will greatly improve English language learning efficiency, as demonstrated from the higher score in English exams, which, in turn, satisfied parental expectations. Here, the instrumental motivation acts as a mediating agent to cultivate self-regulated strategies, especially in goal setting, time management, and attention control. In this regarding, external expectations are related to Chinese EFL learners' online self-regulated English learning [28,81-84].

Moreover, the findings in the present study also supported gender difference in online English learning motivation. Past studies found that gender impacts on longitudinal changes in motivation. Such impacts were subject-sensitive, and gender difference in motivation might widen in the subject of English [85]. Many studies reported that female students usually had greater motivation that male students in English learning [14-16]. This study provided evidence of gender difference in online English learning motivation. In contrast, the non-significance of gender difference in other variables indicated that both female and male students behave similarly regarding their anxiety and learner beliefs. Meanwhile, gender difference in online English learning motivation did not significantly influence students' online self-regulated English learning.

\section{Conclusions}

This study comprehensively investigated the relationship between self-regulated learning and three key learner characteristics, namely, learner beliefs, learning anxiety and motivation, in the online English learning context. Its findings confirmed the effects of online English learner beliefs and online English learning anxiety on online self-regulated English learning. In addition, its findings also demonstrated the mediating effect of online English learning motivation in the associations between 
online English learner beliefs and online self-regulated English learning, and between online English learning anxiety and online self-regulated English learning. To be specific, online English learner beliefs positively predicted self-regulation, learning anxiety negatively predicted self-regulation, and learning motivation was a mediator in these links. These results are consistent with previous findings on the relationships among learner beliefs, anxiety, motivation and self-regulation $[28,32,43,72,78,81]$. As such, positive learner beliefs, less learning anxiety and greater learning motivation are beneficial to Chinese EFL learners' online self-regulated English learning at tertiary level.

Building on the above findings, we summarized the critical characteristics of successful online English learners: (1) driven by integrative or instrumental motivation; (2) exhibiting an appropriate range of emotional attachment; (3) constantly reflecting on their English learning performance; (4) perceiving and understanding the value of English learning; (5) possessing an internal locus of self-evaluation and control; (6) exhibiting self-directed English learning skills towards a specific target or goal; (7) having interpersonal, collaborative and communication skills; (8) possessing good self-control of English learning anxiety, especially during tests; (9) treating the negative evaluations with peace and calm; (10) presenting self-directed learning skills during the implementation of time management and various cognitive learning strategies; (11) exhibiting enough competence in handling online learning tools and technologies.

The relevant pedagogical implications are also discussed. First, teachers are encouraged to raise students' awareness and help them realize the importance of written English. The perceived values and recognition of written English activate integrative motivation, which will promote a better reciprocal and transcultural understanding across the languages. To enhance students' perceived value of written English, teachers could recommend various online resource associated with mass English cultural topics. Second, teachers are also encouraged to set up group discussion on asynchronous discussion forums, which are open-ended and unmoderated, in order to promote interpersonal skills and social engagement. The group discussion should focus on a specific topic, activity or project, such as a capstone project or simply a case study. Students are allowed to solicit information from their peers, making it possible for others to overview a structured online discussion. Third, if teachers expect the students to be highly motivated in virtual environments, they are recommended to transmit realistic benefits through effective instructions. For instance, self-contained instructional modules should be established by online authoring tools and scripting language. This can simulate exploratory activities for students to practice their self-regulated skills. Fourth, various collaborative activities should be designed, such as sharing documents related to a group project or a group presentation on a topic or case study. Group members are instructed and encouraged to discuss their presentation content via emails, videoconferencing and online chat. Teachers should give timely online corrective written feedback to improve students' English learning performance, while activating their integrative and instrumental motivation, so as to suppress learning anxiety and foster self-regulated learning skills. Fifth, teachers are encouraged to liberate learners from numerous writing practices and provide opportunities for students to learn more about English culture and history. English writing topics should be as open and inclusive as possible, and leave more space for students to reflect on the cultural meaning behind different topics. As a consequence, students could become more flexible in learning English written skills in an efficient yet enjoyable manner.

Several limitations in the present study need to be addressed in future research. First, we recruited students taught by different teachers. This deserved additional multi-level analyses to parse out the effect of different teachers. Second, our research findings were primarily dependent upon self-reported data collected by questionnaire items rather than actual behaviors reflecting learner beliefs, anxiety, motivation and self-regulation. In this respect, qualitative studies are recommended in order to better interpret the above-mentioned constructs through the detailed analyses of texts and audio files in the course of online English language learning. Third, future relevant studies should consider the possible effects of age and gender on online learning motivation and their role in the link between motivation and self-regulation by increasing sample size and including other grades. Fourth, more relevant 
studies should be conducted to further explore the complexity regarding the interactional relations among observed variables, measured within the different latent constructs of learner beliefs, anxiety, motivation and self-regulation, thereby yielding more useful and pedagogical implications for both online English learners and educators.

Author Contributions: Conceptualization, W.W.; Data curation, W.W.; Funding acquisition, J.Z.; Investigation, W.W.; Methodology, W.W.; Project administration, J.Z.; Software, W.W.; Writing-original draft, W.W.; Writing - review and editing, J.Z. All authors have read and agreed to the published version of the manuscript.

Funding: This research was funded by National Social Science Fund of China, grant number 14BYY080.

Acknowledgments: The authors express sincere thanks to all the participants and anonymous reviewers.

Conflicts of Interest: The authors declare no conflict of interest.

\section{References}

1. Baran, E.; Correia, A.P. A professional development framework for online teaching. TechTrends 2014, 58, 95-101. [CrossRef]

2. Rogers, D.L. A paradigm shift: Technology integration for higher education in the new millennium. AACE J. 2000, 1, 19-33.

3. Lai, C.; Zhu, W.M.; Gong, G. Understanding the quality of out-of-class English learning. TESOL Q. 2015, 49, 278-308. [CrossRef]

4. Wang, Y.; Baker, R. Content or platform: Why do students complete MOOCs? J. Online Learn. Teach. 2015, 11, 17-30.

5. Jordan, K. Initial trends in enrolment and completion of massive open online courses. Int. Rev. Res. Open Distance Learn. 2014, 15, 133-160. [CrossRef]

6. Ellis, R. The Study of Second Language Acquisition; Oxford University Press: Oxford, UK, 1994.

7. Dörnyei, Z. Conceptualizing learner characteristics in a complex, dynamic world. In Complexity Theory and Language Development: In Celebration of Diane Larsen-Freeman; John Benjamins Publishing Company: Philadelphia, PA, USA, 2017; pp. 79-96.

8. Dabbagh, N. The online learner: Characteristics and pedagogical implications. Contemp. Issues Technol. Teach. Educ. 2007, 7, 217-226.

9. Dörnyei, Z. Individual differences: Interplay of learner characteristics and learning environment. Lang. Learn. 2009, 59, 230-248. [CrossRef]

10. Ketenci, T.; Calandra, B.; Margulieux, L.; Cohen, J. The Relationship between Learner Characteristics and Student Outcomes in a Middle School Computing Course: An Exploratory Analysis Using Structural Equation Modeling. J. Res. Technol. Educ. 2019, 51, 63-76. [CrossRef]

11. Ellis, R. Learner beliefs and language learning. Asian EFL J. 2008, 10, 7-25.

12. Horwitz, E.K. Foreign and second language anxiety. Lang. Teach. 2010, 43, 154-167. [CrossRef]

13. Horwitz, E.K.; Tallon, M.; Luo, H. Foreign language anxiety. Anxiety in Schools: The Causes, Consequences, and Solutions for Academic Anxieties; Cassady, J.C., Ed.; Peter Lang: New York, NY, USA, 2009; pp. 96-118.

14. Ardasheva, Y.; Tong, S.S.; Tretter, T.R. Validating the English Language Learner Motivation Scale (ELLMS): Pre-college to measure language learning motivational orientations among young ELLs. Learn. Individ. Differ. 2012, 22, 473-483. [CrossRef]

15. You, C.J.; Dörnyei, Z. Language learning motivation in China: Results of a large-scale stratified survey. Appl. Linguist. 2016, 37, 495-519. [CrossRef]

16. Lai, C.; Shum, M.; Tian, Y. Enhancing learners' self-directed use of technology for language learning: The effectiveness of an online training platform. Comput. Assist. Lang. Learn. 2016, 29, 40-60. [CrossRef]

17. Hafner, C.; Miller, L. Fostering learner autonomy in English for science: A collaborative digital video project in a technological learning environment. Lang. Learn. Technol. 2011, 15, 68-86.

18. Zimmerman, B.J. Becoming a self-regulated learner: An overview. Theory Into Pract. 2002, 41, 64-70. [CrossRef]

19. Schunk, D.H.; Zimmerman, B.J. Self-Regulated Learning: From Teaching to Self-Reflective Practice; Guilford Press: New York, NY, USA, 1998. 
20. Barnard, L.; Lan, W.Y.; To, Y.M.; Paton, V.O.; Lai, S.L. Measuring self-regulation in online and blended learning environments. Internet High. Educ. 2009, 12, 1-6. [CrossRef]

21. Lynch, R.; Dembo, M. The relationship between self-regulation and online learning in a blended learning context. Int. Rev. Res. Open Distrib. Learn. 2004, 5, 1-16. [CrossRef]

22. Dörnyei, Z.; Ryan, S. The Psychology of the Language Learner Revisited; Routledge: Mullica, NJ, USA, 2015.

23. Zimmerman, B.J.; Schunk, D.H. Self-Regulated Learning and Academic Achievement: Theoretical Perspectives; Routledge: Mullica, NJ, USA, 2001.

24. Tseng, W.T.; Liu, H.; Nix, J.M.L. Self-regulation in language learning: Scale validation and gender effects. Percept. Mot. Ski. 2017, 124, 531-548. [CrossRef]

25. Zimmerman, B.J. Self-regulated learning and academic achievement: An overview. Educ. Psychol. 1990, 25, 3-17. [CrossRef]

26. Zimmerman, B.J. Investigating Self-Regulation and Motivation: Historical Background, Methodological Developments, and Future Prospects. Am. Educ. Res. J. 2008, 45, 166-183. [CrossRef]

27. Schunk, D.H.; Ertmer, P.A. Self-regulation and academic learning: Self-efficacy enhancing interventions. In Handbook of Self-regulation; Academic Press: Salt Lake, UT, USA, 2000.

28. Schunk, D.H.; Zimmerman, B.J. Motivation and Self-regulated Learning: Theory, Research, and Applications; Routledge: Mullica, NJ, USA, 2012.

29. Littlejohn, A.; Hood, N.; Milligan, C.; Mustain, P. Learning in MOOCs: Motivations and self-regulated learning in MOOCs. Internet High. Educ. 2016, 29, 40-48. [CrossRef]

30. Cho, M.-H.; Heron, M.L. Self-regulated learning: The role of motivation, emotion, and use of learning strategies in students' learning experiences in a self-paced online mathematics course. Distance Educ. 2015, 36, 80-99. [CrossRef]

31. Lai, C.; Gu, M. Self-regulated out-of-class language learning with technology. Comput. Assist. Lang. Learn. 2011, 24, 317-335. [CrossRef]

32. Zheng, C.; Liang, J.C.; Li, M.; Tsai, C.C. The relationship between English language learners' motivation and online self-regulation: A structural equation modelling approach. System 2018, 76, 144-157. [CrossRef]

33. Ertmer, P.A.; Newby, T.J. The Expert Learner: Strategic, Self-Regulated, and Reflective. Instr. Sci. 1996, 24, 1-24. [CrossRef]

34. Tanaka, K.; Ellis, R. Study abroad, language proficiency, and learner beliefs about language learning. JALT J. 2003, 25, 63-85. [CrossRef]

35. Kaypak, E.; Ortaçtepe, D. Language learner beliefs and study abroad: A study on English as a lingua franca (ELF). System 2014, 42, 355-367. [CrossRef]

36. Kalaja, P.; Barcelos, A.F. Beliefs about SLA: New Research Approaches; Springer: New York, NY, USA, 2007.

37. Larsen-Freeman, D. Second language acquisition research: Staking out the territory. TESOL Q. 1991, 25, 315-350. [CrossRef]

38. Yang, N.D. The relationship between EFL learners' beliefs and learning strategy use. System 1999, 27, 515-535. [CrossRef]

39. Horwitz, E.K. Surveying Student Beliefs about Language Learning. In Learner Strategies in Language Learning; Wenden, A.L., Rubin, J., Eds.; Prentice-Hall: Upper Saddle River, NJ, USA, 1987; pp. 119-129.

40. Wenden, A.L. What do second-language learners know about their language learning? A second look at retrospective accounts. Appl. Linguist. 1986, 7, 186-201. [CrossRef]

41. Wenden, A.L. Helping language learners think about learning. Engl. Lang. Teach. J. 1986, 40, 3-12. [CrossRef]

42. Bandura, A. Social cognitive theory of self-regulation. Organ. Behav. Hum. Decis. Process. 1991, 50, $248-287$. [CrossRef]

43. Schunk, D.H. Goal setting and self-efficacy during self-regulated learning. Educ. Psychol. 1990, 25, 71-86. [CrossRef]

44. Na, Z. A study of high school students' English learning anxiety. Asian EFL J. 2007, 9, $22-34$.

45. Liu, M. Anxiety in Chinese EFL students at different proficiency levels. System 2006, 34, 301-316. [CrossRef]

46. Horwitz, E.K.; Horwitz, M.B.; Cope, J. Foreign language classroom anxiety. Mod. Lang. J. 1986, 70, $125-132$. [CrossRef]

47. Pichette, F. Second language anxiety and distance language learning. Foreign Lang. Ann. 2009, 42, 77-93. [CrossRef] 
48. Burge, E.J.; Howard, J.L.; Ironside, D.J. Mediation in Distance Learning: An Investigation of the Role of Tutoring; Ontario Institute for Studies in Education (OISE): Toronto, ON, Canada, 1991.

49. Coryell, J.E.; Clark, M.C. One right way, intercultural participation, and language learning anxiety: A qualitative analysis of adult online heritage and nonheritage language learners. Foreign Lang. Ann. 2009, 42, 483-504. [CrossRef]

50. Thompson, A.S.; Lee, J. The impact of experience abroad and language proficiency on language learning anxiety. TESOL Q. 2014, 48, 252-274. [CrossRef]

51. Barak, M.; Watted, A.; Haick, H. Motivation to learn in massive open online courses: Examining aspects of language and social engagement. Comput. Educ. 2016, 94, 49-60. [CrossRef]

52. Spada, N.; Lightbrown, P. Instruction and the development of questions in L2 classrooms. Stud. Second Lang. Acquis. 1993, 15, 205-224. [CrossRef]

53. Gardner, R.C.; Lambert, W.E. Attitudes and Motivation in Second-Language Learning; Newbury House Publisher: Rowley, MA, USA, 1978.

54. Gardner, R.C. Integrative motivation and second language acquisition. Motiv. Second Lang. Acquis. 2001, 23, 1-19.

55. Lamb, M. The motivational dimension of language teaching. Lang. Teach. 2017, 50, 301-346. [CrossRef]

56. Ryan, R.M.; Deci, E.L. Bridging the research traditions of task/ego involvement and intrinsic/extrinsic motivation: Comment on Butler. J. Educ. Psychol. 1989, 81, 265-268. [CrossRef]

57. Lim, D.H.; Kim, H. Motivation and learner characteristics affecting online learning and learning application. J. Educ. Technol. Syst. 2003, 31, 423-439. [CrossRef]

58. Kormos, J.; Csizer, K. The interaction of motivation, self-regulatory strategies, and autonomous learning behavior in different learner groups. TESOL Q. 2014, 48, 275-299. [CrossRef]

59. Transform Your Writing Skills. Prepare for College-level Writing and Research. Available online: https: //www.coursera.org/specializations/academic-english\#instructors (accessed on 1 September 2018).

60. Schumacker, R.E.; Lomax, R.G. A Beginner's Guide to Structural Equation Modeling, 3rd ed.; Routledge: New York, NY, USA, 2010.

61. Hu, L.; Bentler, P.M. Cutoff criteria for fit indexes in covariance structure analysis: Conventional criteria versus new alternatives. Struct. Equ. Modeling A Multidiscip. J. 1999, 6, 1-55. [CrossRef]

62. Byrne, B.M. Structural Equation Modeling with AMOS: Basic Concepts, Applications, and Programming; Routledge: New York, NY, USA, 2010.

63. Rosenthal, R.; Rosnow, R.L. Essentials of Behavioral Research: Methods and Data Analysis; McGraw-Hill: New York, NY, USA, 1991.

64. Wen, Z.; Ye, B. Analyses of mediating effects: The development of methods and models. Adv. Methods Pract. Psychol. Sci. 2014, 22, 731-745. (In Chinese) [CrossRef]

65. Preacher, K.J.; Hayes, A.F. Asymptotic and resampling strategies for assessing and comparing indirect effects in multiple mediator models. Behav. Res. Methods 2008, 40, 879-891. [CrossRef] [PubMed]

66. Rosseel, Y. lavaan: An R Package for Structural Equation Modeling. J. Stat. Softw. 2012, 48, 1-36. [CrossRef]

67. Hope, R.M. Rmisc: Ryan Miscellaneous. R Package Version. 2013, 1(5). Available online: https://cran.rproject.org/web/packages/Hmisc/index.html (accessed on 24 January 2020).

68. Epskamp, S.; Stuber, S. semPlot: Path Diagrams and Visual Analysis of Various SEM Packages' Output. R Package Version. 2014,1(1). Available online: https://github.com/SachaEpskamp/semPlot (accessed on 24 January 2020).

69. R Development Core Team. R: A Language and Environment for Statistical Computing; R Foundation for Statistical Computing: Vienna, Austria, 2014.

70. Hair, J.F.; Black, W.C.; Babin, B.J.; Anderson, R.E.; Tatham, R.L. Multivariate Data Analysis, 6th ed.; Prentice Hall: New York, NY, USA, 2006.

71. Bandura, A. Social cognitive theory: An agentic perspective. Asian J. Soc. Psychol. 2001, 2, 21-41. [CrossRef]

72. Zaykovskaya, I.; Rawal, H.; De Costa, P.I. Learner beliefs for successful study abroad experience: A case study. System 2017, 71, 113-121. [CrossRef]

73. Su-chun, X. A study on the relationship between language learning anxiety and learning strategy use of university students in the computer-based environment. Comput. -Assist. Foreign Lang. Educ. 2012, $23,14$.

74. Dörnyei, Z. New themes and approaches in second language motivation research. Annu. Rev. Appl. Linguist. 2001, 21, 43-59. [CrossRef] 
75. Pintrich, P.R.; Schunk, D.H. Motivation in Education: Theory, Research, and Applications; Prentice Hall: Upper Saddle River, NJ, USA, 2002.

76. Kormos, J.; Kiddle, T.; Csizer, K. System of goals, attitudes and self-related beliefs in second language learning motivation. Appl. Linguist. 2011, 32, 495-516. [CrossRef]

77. Shroff, R.H.; Vogel, D.R.; Coombes, J. Assessing individual-level factors supporting student intrinsic motivation in online discussions: A qualitative study. J. Inf. Syst. Educ. 2008, 19, 111-125.

78. Kizilcec, R.F.; Schneider, E. Motivation as a lens to understand online learners: Toward data-driven design with the OLEI scale. ACM Trans. Comput. -Hum. Interact. 2015, 22, 1-24. [CrossRef]

79. Hao, M.; Liu, M.; Hao, R.P. An empirical study on anxiety and motivation in English as a foreign language. Asian J. Engl. Lang. Teach. 2004, 14, 89-104.

80. Liu, M.; Huang, W. An exploration of foreign language anxiety and English learning motivation. Educ. Res. Int. 2011, 2011, 1-8. [CrossRef]

81. Butler, Y.G. Parental factors in children's motivation for learning English: A case in China. Res. Pap. Educ. 2016, 30, 164-191. [CrossRef]

82. Martirossian, A.; Hartoonian, A. Lowering foreign language anxiety through self-regulated learning strategy use. Engl. Lang. Teach. 2015, 8, 209-222. [CrossRef]

83. Gao, X.S. Parental strategies in supporting Chinese children's learning of English vocabulary. Res. Pap. Educ. 2012, 27, 581-595. [CrossRef]

84. Gao, Y.; Zhou, Y. EFL learning and learners' self-identity changes. Foreign Lang. Educ. 2008, 29, 51-55.

85. Lee, H.; Kim, Y. Korean adolescents' longitudinal change of intrinsic motivation in learning English and mathematics during secondary school years: Focusing on gender difference and school characteristics. Learn. Individ. Differ. 2014, 36, 131-139. [CrossRef]

(C) 2020 by the authors. Licensee MDPI, Basel, Switzerland. This article is an open access article distributed under the terms and conditions of the Creative Commons Attribution (CC BY) license (http://creativecommons.org/licenses/by/4.0/). 